UDC 544.344.015.3: 546.81'86'24

\title{
PHASE DIAGRAM OF THE $\mathrm{SnSb}_{2} \mathrm{Te}_{4}-\mathrm{SnBi}_{2} \mathrm{Te}_{4}$ SYSTEM AND SOME PROPERTIES OF THE $\mathrm{SnSb}_{2-x} \mathrm{Bi}_{x} \mathrm{Te}_{4}$ SOLID SOLUTIONS
}

\author{
A.E.Seidzade, M.B.Babanly \\ M.Nagiev Institute of Catalysis and Inorganic Chemistry, NAS of Azerbaijan \\ babanlymb@gmail.com
}

Received 17.09.2019

\begin{abstract}
Using differential thermal analysis and X-ray diffraction technique phase equilibria in the $\mathrm{SnSb}_{2} \mathrm{Te}_{4}-$ $\mathrm{SnBi}_{2} \mathrm{Te}_{4}$ system were investigated and its $T-x$ diagram was constructed. The system is non-quasibinary due to the incongruent melting of the starting ternary compounds, but it is stable below solidus. The system characterized by a continuous series of substitutional solid solutions with tetradimite-like hexagonal structure. The crystal lattice parameters are a linear function of the composition. Liquidus consists of one curve corresponding to the primary crystallization of solid solutions based on the SnTe compound ( $\alpha$-phase), which interacts with the liquid phase by peritectic reaction ( $\mathrm{L}+\alpha \leftrightarrow \gamma)$ and forms solid solutions based on the $\mathrm{SnSb}_{2} \mathrm{Te}_{4}$ and $\mathrm{SnBi}_{2} \mathrm{Te}_{4}$ compounds. According to the results of powder diffraction patterns, the lattice parameters are determined. It was established that the crystal lattice parameters of solid solutions vary linearly with composition.
\end{abstract}

Keywords: $\mathrm{SnSb}_{2} \mathrm{Te}_{4}-\mathrm{SnBi}_{2} \mathrm{Te}_{4}$ system, phase equilibria, solid solutions, tetradymite-like structure, tinbismuth-antimony tellurides.

doi

\section{Introduction}

Chalcogenides of $p$-block elements are used as matrix phases in the design of materials for energy conversion and storage. Such materials include, for example, photovoltaic cells in solar panels or semiconductor-ferromagnetic and thermoelectric materials in new-generation generators and refrigerators [1-4].

Tetradymite-like layered binary and ternary compounds of the homological series $\left(\mathrm{A}^{\mathrm{IV}} \mathrm{Te}\right)_{m}\left(\mathrm{~B}^{\mathrm{V}}{ }_{2} \mathrm{Te}_{3}\right)_{n}\left(\mathrm{~A}^{\mathrm{IV}}=\mathrm{Ge}, \mathrm{Sn}, \mathrm{Pb} ; \mathrm{B}^{\mathrm{V}}=\mathrm{Sb}\right.$, $\mathrm{Bi})$, particularly compounds $\mathrm{A}^{\mathrm{IV}} \mathrm{B}_{2} \mathrm{Te}_{4}$ type, are long studied as thermoelectric materials. Ternary tetradymite-like compounds have a complex multilayer structure, and their lattice thermal conductivity is lower than the binary compounds $\mathrm{A}^{\mathrm{IV}} \mathrm{Te}$ and $\mathrm{B}_{2}^{\mathrm{V}} \mathrm{Te}_{3}$, which is important for their use in thermoelectricity [5-8].

Recent studies have shown that these compounds are topological insulators (TIs) [913] and have a very wide range of potential applications, including optoelectronics, plasmanics, spintronics, quantum computing [14-18].

Reliable data on phase equilibria and thermodynamic properties of phases is of key importance in developing methods and optimizing the conditions for the design and growth of crystals of multicomponent inorganic materials $[19,20]$. The solid-phase equilibria and thermodynamic properties of the $\mathrm{SnTe}-\mathrm{Bi}_{2} \mathrm{Te}_{3}-\mathrm{Te}$ and $\mathrm{PbTe}-\mathrm{Bi}_{2} \mathrm{Te}_{3}-\mathrm{Te}$ systems were studied by the EMF method in [21, 22], and the thermodynamic properties of the $\mathrm{SnSb}_{2} \mathrm{Te}_{4}$ compound were studied in [23].

Present work represents the results of study of phase equilibria in the $\mathrm{SnSb}_{2} \mathrm{Te}_{4}-$ $\mathrm{SnBi}_{2} \mathrm{Te}_{4}$ system.

The $\mathrm{SnSb}_{2} \mathrm{Te}_{4}$ compound which formed in the $\mathrm{SnTe}-\mathrm{Sb}_{2} \mathrm{Te}_{3}$ system melts incongruently at $600^{\circ} \mathrm{C}$ [24]. It crystallizes in a hexagonal tetradimite-like structure $(S p . G r . R-3 \mathrm{~m})$ with unit cell parameters $a=4.2940 \AA$ and $c=41.548$ $\AA$ [25].

The $\mathrm{SnTe}-\mathrm{Bi}_{2} \mathrm{Te}_{3}$ system contains three ternary compounds: $\mathrm{SnBi}_{2} \mathrm{Te}_{4}, \mathrm{SnBi}_{4} \mathrm{Te}_{7}$, and $\mathrm{SnBi}_{6} \mathrm{Te}_{10}$, which melt with decomposition according to the peritectic reaction at 600,590 and $582^{\circ} \mathrm{C}$, respectively [26]. The parameters of the hexagonal crystal lattice $\left(S p \cdot G r . \mathrm{R}^{-} 3 \mathrm{~m}\right)$ of $\mathrm{SnBi}_{2} \mathrm{Te}_{4}$ are: $a=4.386 \AA, c=41.511 \AA$, and $a$ $=4.40283 \AA$ [27], $c=41.7139 \AA$ [28].

\section{Experimental part}

The initial binary compounds SnTe, $\mathrm{Sb}_{2} \mathrm{Te}_{3}$, and $\mathrm{Bi}_{2} \mathrm{Te}_{3}$ were synthesized by melting 
of high purity (99.995\%, Alfa Aesar) elementary components in evacuated $(\sim 10-2 \mathrm{~Pa})$ ampoules at temperatures $\sim 50^{\circ} \mathrm{C}$ higher than their melting points, followed by slow cooling in the switched off ovens. The obtained binary compounds were identified by X-ray diffraction (XRD) and differential thermal analyzes (DTA). Obtained values of peritectic decomposition temperatures and crystal lattice parameters (Table) are in good agreement with the data given in [24, 27].

Some properties of the starting compounds and solid solutions for $\mathrm{SnSb}_{2} \mathrm{Te}_{4}-\mathrm{SnBi}_{2} \mathrm{Te}_{4}$ system

\begin{tabular}{|c|c|c|}
\hline $\begin{array}{c}\text { Composition, } \\
\text { mol. } \%\end{array}$ & $\begin{array}{c}\text { Thermal effects, } \\
{ }^{0} \mathrm{C}\end{array}$ & $\begin{array}{c}\text { Hexagonal parameters of the crystal lattice, } \\
\AA(S p . g r . R-3 m l)\end{array}$ \\
\hline $\mathrm{SnSb}_{2} \mathrm{Te}_{4}$ & 594,625 & $a=4.2957(3), c=41.542(4)$ \\
\hline 20 & $595-598,625$ & $a=4.3147(4), c=41.562(5)$ \\
\hline 40 & $597-601,624$ & $a=4.3382(4), c=41.578(5)$ \\
\hline 60 & $598-602,624$ & $a=4.3625(3), c=41.584(5)$ \\
\hline 80 & $600-604,623$ & $a=4.3846(3), c=41.603(4)$ \\
\hline $\mathrm{SnBi}_{2} \mathrm{Te}_{4}$ & 606,620 & $a=4.4035(4), c=41.623(5)$ \\
\hline
\end{tabular}

Initial ternary compounds and intermediate alloys of the system under study were prepared from stoichiometric quantities of presynthesized binary compounds in evacuated quartz tubes by melting at $700^{\circ} \mathrm{C}$. Obtained samples of $0.5 \mathrm{~g}$ mass were quenched by ejection of ampoules from the hot furnace into cold water, then they were annealed at $450^{\circ} \mathrm{C}(500 \mathrm{~h})$, in order to reach the state closest to equilibrium.

DTA analysis were conducted on a NETZSCH 404 F1 Pegasus differential scanning calorimeter from room temperature to $700^{\circ} \mathrm{C}$ with a heating rate of $10^{\circ} \mathrm{C} / \mathrm{min}$. The temperatures of thermal effects were determined mainly from the heating curves. The accuracy of the temperature measurement was $\pm 2^{0}$.
Analysis of crystal structures of the initial compounds and intermediate alloys was performed using X-ray powder diffraction (PXRD) data obtained on a Bruker D2 Phaser diffractometer using $\mathrm{Cu} K_{\alpha 1}$-radiation $(\lambda=1.54056 \AA)$ at room temperature. The unit cell parameters of initial compounds and intermediate alloys were calculated by indexing of powder patterns using Topas V3.0 software.

\section{Results and discussion}

$\mathrm{X}$-ray powder diffraction patterns of the starting compounds and some annealed alloys of the $\mathrm{SnSb}_{2} \mathrm{Te}_{4}-\mathrm{SnBi}_{2} \mathrm{Te}_{4}$ system are shown in Figure 1.

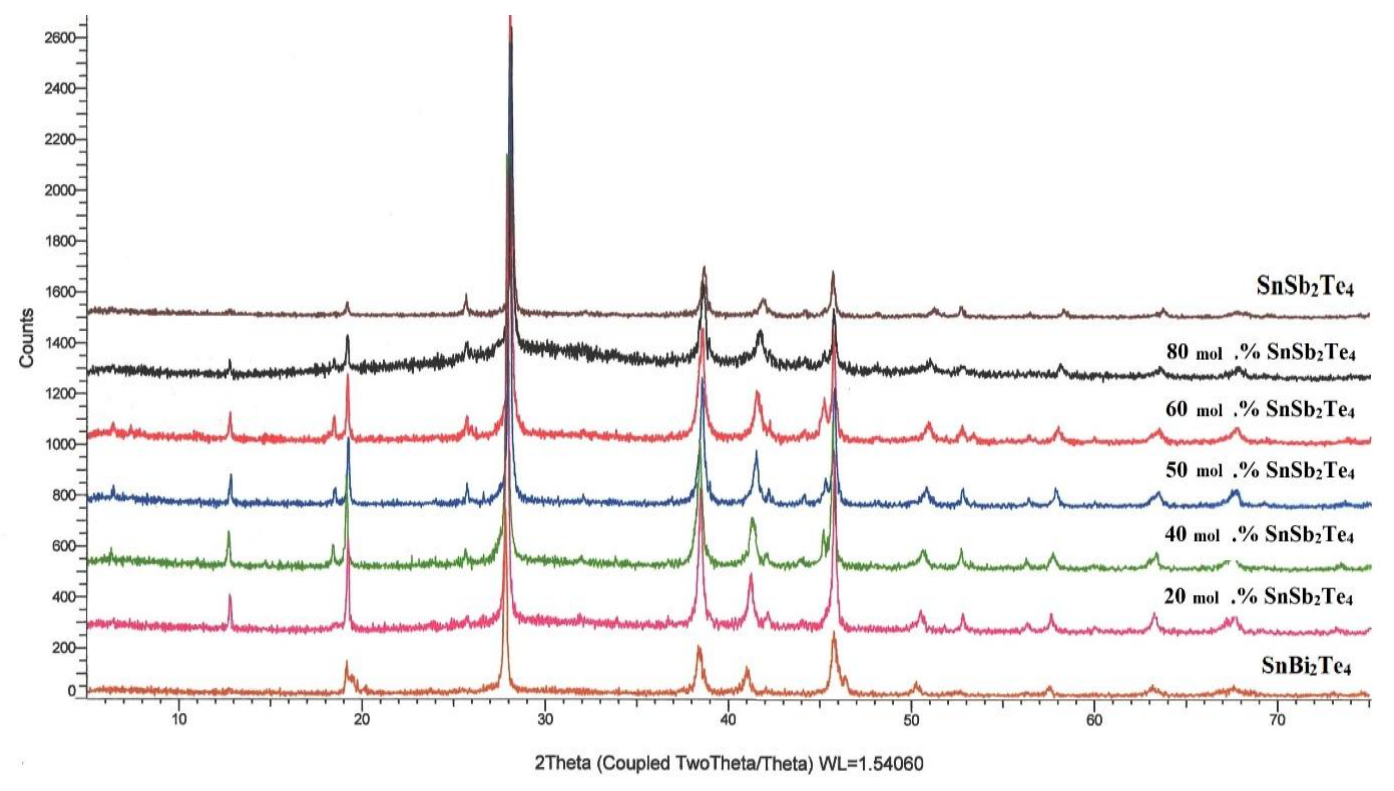

Fig.1. XRD powder patterns of some alloys of the $\mathrm{SnSb}_{2} \mathrm{Te}_{4}-\mathrm{SnBi}_{2} \mathrm{Te}_{4}$ system. 
As can be seen, all samples have qualitatively identical diffraction patterns with some slight shift of reflection lines that is typical for substitutional solid solutions with tetradymitelike hexagonal structure.

Based on the DTA data (table), the $T-x$ diagram of the $\mathrm{SnSb}_{2} \mathrm{Te}_{4}-\mathrm{SnBi}_{2} \mathrm{Te}_{4}$ system was constructed (Figure 2). It was found that the system is non-quasibinary due to the incongruent nature of the melting points of both starting compounds, but it is stable below solidus. The system is characterized by the formation of continuous series of solid solutions ( $\gamma$-phase).

Considering the fact that the $\mathrm{SnB}_{2}^{v} \mathrm{Te}_{4}$ compounds melt with decomposition by peritectic reactions L+ $\alpha \leftrightarrow \mathrm{SnBTe}_{4}[23,25]$ in the quasi binary systems $\mathrm{SnTe}-\mathrm{B}_{2}^{v} \mathrm{Te}_{3}\left(\mathrm{~B}^{\mathrm{v}}-\mathrm{Sb}, \mathrm{Bi}\right)(\alpha$ - solid solutions based on SnTe), it can be noted that firstly the $\alpha$-phase crystallizes from liquid phase in the $\mathrm{SnSb}_{2} \mathrm{Te}_{4}-\mathrm{SnBi}_{2} \mathrm{Te}_{4}$ system. This leads to the formation of a two-phase region: $\mathrm{L}+\alpha$. Further, monovariant peritectic reaction $\mathrm{L}+\alpha \leftrightarrow \gamma$ proceeds in the system.
The transition of the system from twoand three-phase state to a single-phase state may seems erroneous, since this contradicts the law of construction of the phase diagrams. However, this contradiction is only apparent. Since the total composition of the investigated samples are on $T-x$ plane of $\mathrm{SnSb}_{2} \mathrm{Te}_{4}-\mathrm{SnBi}_{2} \mathrm{Te}_{4}$ section, the peritectic reaction ends with the simultaneous disappearance of both initial phases.

The temperatures of primary crystallization and peritectic reaction were determined from the data of the cooling curves (triangles in Figure $2 a$ ). The temperatures of completion of the peritectic reaction determined from the heating curves of annealed alloys (dark circles in Figure $2 a$ ).

By identifying powder diffractograms, the parameters of the crystal lattices of solid solutions were determined (Table). Based on them the graphs of the dependence of the lattice parameters on the composition were constructed (Figure $2 b$ ). It can be seen that the parameters of the hexagonal lattice are a linear function on the composition of the composition, i.e. obey Vegard's rule.

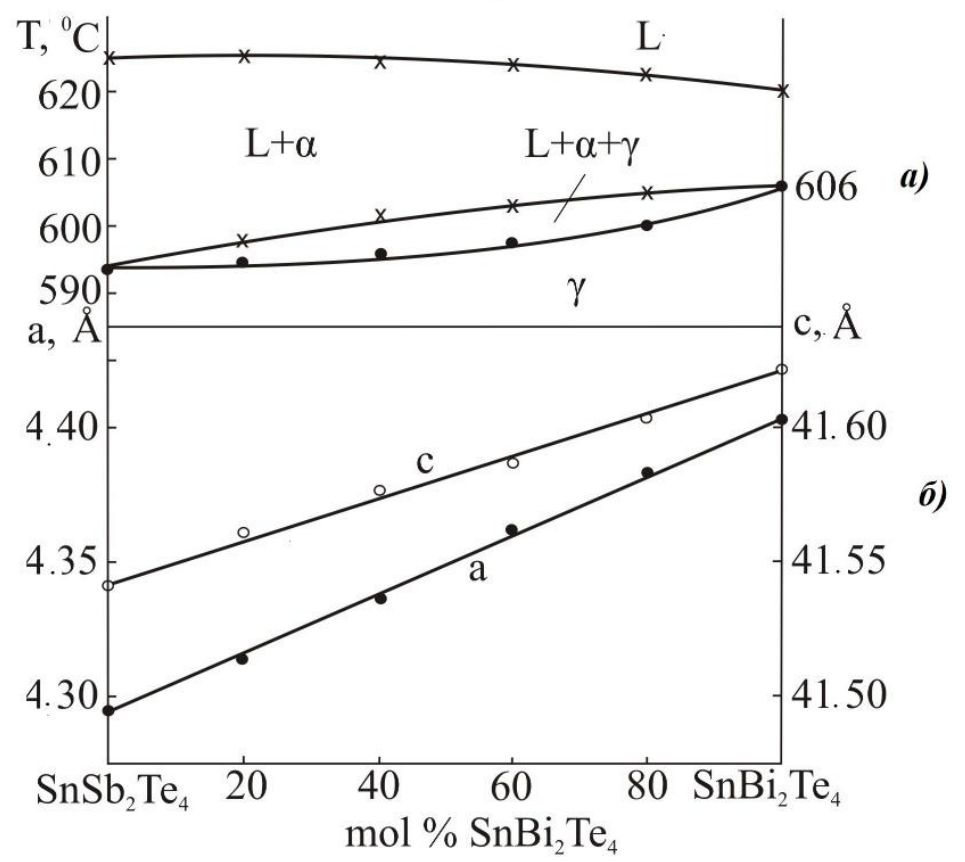

Fig.2. Phase diagram $(a)$ and the dependence of the lattice parameters (b) on composition for the $\mathrm{SnSb}_{2} \mathrm{Te}_{4}-\mathrm{SnBi}_{2} \mathrm{Te}_{4}$ system. 


\section{Conclusion}

New data on phase equilibria in the $\mathrm{SnSb}_{2} \mathrm{Te}_{4}-\mathrm{SnBi}_{2} \mathrm{Te}_{4}$ system obtained by DTA and XRD were presented. The system as a whole is non-quasibinary due to the incongruent melting of the starting compounds, but it is stable in the subsolidus. The system is characterized by the formation of a continuous series of solid solutions with tetradimite-like layered structure. The lattice parameters of solid solutions, which are a linear function of the composition, are determined. The obtained solid solutions of a given composition $\mathrm{SnSb}_{2-x} \mathrm{Bi}_{x} \mathrm{Te}_{4}$ are of practical interest as potential thermoelectrics and topological insulators.

\section{References}

1. Ahluwalia G.K. (Ed.). Applications of Chalcogenides: S, Se, and Te. Springer. 2016. 461 p.

2. Kolobov A.V., Tominaga J. Two-Dimensional Transition-Metal Dichalcogenides. Springer International Publishing, 2016. 538 p.

3. Gao M-R., Xu Y-F., Jiang J., Yu S-H. Nanostructured metal chalcogenides: synthesis, modification, and applications in energy conversion and storage devices. Chem. Soc. Reviews. 2013. V. 4. P. 2986-3017.

4. Kanatzidis M.G. Discovery-Synthesis, Design, and Prediction of Chalcogenide Phases. Inorg. Chem. 2017. V. 56 (6). P. 3158-3173.

5. Gayner C., Kar. K.K. Recent advances in thermoelectric materials. Progress Mater. Sci. 2016. V. 83. P. 330-382.

6. Shelimova L.E., Karpinski O.G., Konstantinov P.P., Avilov E.S., Kretova M.A., Zemskov V.S. Crystal Structures and Thermoelectric Properties of Layered Compounds in the $\mathrm{ATe}-\mathrm{Bi}_{2} \mathrm{Te}_{3}(\mathrm{~A}=$ $\mathrm{Ge}, \mathrm{Sn}, \mathrm{Pb})$ Systems. Inorg. Mater. 2004. P. 451.

7. Shevelkov A.V. Chemical aspects of thermoelectric materials engineering. Russ. Chem. Rev. 2008. V. 77. P.1-19.

8. Zhang X, Zhao L-D. Thermoelectric materials: Energy conversion between heat and electricity. J. Materiomics. 2015. V. 1. P. 92-105.

9. Eremeev S.V., Landolt G., Menshchikova T.V., Slomski V., Koroteev Y.M., Aliev Z.S, Babanly M.B., Henk J., Ernst A., Patthey L., Khajetoorians A., Wiebe J., Echenique P.M., Tsirkin S.S., Amiraslanov I.R., Dil J.H., Chulkov E.V. Atom-specific spin mapping and buried topological states in a homological series of topological insulators. Nature Communications. 2012. V. 3. P. 635(7).

10. Niesner D., Otto S., Hermann V., Fauster Th., Menshchikova T.V., Eremeev S.V., Aliev Z.S.,
Amiraslanov I.R., Echenique P.M., Babanly M.B., Chulkov E.V. Bulk and surface electron dynamics in a p-type topological insulator $\mathrm{SnSb}_{2} \mathrm{Te}_{4}$. Phys. Rev. B. 2014. V.89. P. 081404 (5).

11. Shvets I.A., Klimovskikh I.I., Aliev Z.S., Babanly M.B., Sánchez-Barriga J., Krivenkov M., Shikin A.M., Chulkov E.V. Impact of stoichiometry and disorder on the electronic structure of the $\mathrm{PbBi}_{2} \mathrm{Te}_{4-\mathrm{x}} \mathrm{Se}_{\mathrm{x}}$ topological insulator. Phys. Rev. B. 2017. V. 96. P. 235124-7.

12. Vergniory M.G., Menshchikova T.V., Silkin I.V., Koroteev Yu.M., Eremeev S.V., Chulkov E.V. Electronic and spin structure of a family of Snbased ternary topological insulators. Phys. Rev. B 92. 2015. P. 045134.

13. Papagno M., Eremeev S., Fujii J., Aliev Z.S., Babanly M.B., Mahatha S., Vobornik I., Mamedov N., Pacile D., Chulkov E.V. Multiple Coexisting Dirac Surface States in Three-Dimensional Topological Insulator $\mathrm{PbBi}_{6} \mathrm{Te}_{10}$. ACS Nano. 2016. V. 10. P. 3518-3524.

14. Viti L., Coquillat D., Politano A., Kokh K.A., Aliyev Z.S., Babanly M.B., Tereshchenko O.E., Knap W., Chulkov E.V., Vitiello M.S. Plasma-Wave Terahertz Detection Mediated by Topological Insulators Surface States. Nano Lett. 2016. V.16. P. 80-87.

15. Peng H., Dang W., Cao J., Chen Y., Wu D., Zheng W., Li H., Shen Z. X., Z. Liu. Topological insulator nanostructures for near-infrared transparent flexible electrodes. Nature Chem. 2012. V. 4. P. 281-286.

16. Nechaev I., Aguilera I., V. De Renzi, A. di Bona, Lodi Rizzini A., Mio A. M., Nicotra G., Politano A., Scalese S., Aliev Z.S., Babanly M.B., Friedrich C., Blügel S., Chulkov E.V. Quasiparticle spectrum and plasmonic excitations in the topological insulator $\mathrm{Sb}_{2} \mathrm{Te}_{3}$. Phys. Rev. 2015. V. $91 \mathrm{~B}$. P. 245123.

17. Vobornik I., Manju U., Fujii J., Borgatti F., Torelli P., Krizmancic D., Hor Y., Cava R. J., Panaccione G. Magnetic Proximity Effect as a Pathway to Spintronic Applications of Topological Insulators. Nano Lett. 2011. V. 11. P. 4079-4082.

18. Nayak C., Simon S.H., Stern A., Freedman M., Das Sarma S. Non-Abelian anyons and topological quantum computation. Rev. Mod. Phys. 2008. V. 80. P. 1083-1159.

19. Babanly M.B., Chulkov E.V., Aliev Z.S., Shevelkov A.V., Amiraslanov I.R. Phase Diagrams in Materials Science of Topological Insulators Based on Metal Chalcogenides. Russian J. Inorg. Chem. 2017. V. 62. P. 1703-1729.

20. Imamaliyeva S. Z., Babanly D.M., Tagiev D.B., Babanly M.B. Physicochemical Aspects of Development of Multicomponent Chalcogenide Phases Having the $\mathrm{Tl}_{5} \mathrm{Te}_{3}$ Structure: A Review. Russ. J. Inorg. Chem. 2018. V. 13. P. 1703-1727. 
21. Babanly M.B., Guseinov F.N., Dashdyeva G.B., Yusibov Yu.A. Homogeneity Ranges and Thermodynamic Properties of Ternary Phases in the $\mathrm{SnTe}-\mathrm{Bi}_{2} \mathrm{Te}_{3}-\mathrm{Te}$ System. Neorgan. Mater. 2011. V. 47. P. 284-288.

22. Babanly M.B., Shevel'kov A.V., Guseinov F.N., Babanly D.M. PbTe- $-\mathrm{Bi}_{2} \mathrm{Te}_{3}-\mathrm{Te}$ system studied by emf measurements. Inorg. Mater. 2011. V. 47. P. 712-716.

23. Guseinov F.N., Seidzade A.E., Yusibov Yu.A., Babanly M.B. Thermodynamic Properties of the $\mathrm{SnSb}_{2} \mathrm{Te}_{4}$ Compound. Neorganicheskie Materialy. 2017. V. 53. P. 347-350.

24. Elagina E.I., Abrikosov N.Kh. Systems PbTe$\mathrm{Bi}_{2} \mathrm{Te}_{3}$ and $\mathrm{SnTe}-\mathrm{Sb}_{2} \mathrm{Te}_{3}$. Inorg. Chem. 1959. V. 4. P. 1638-1642.

25. Mario Sergio da Luz, Fernando Pacheco Tofanello, Murilo Senhuki Esposito, Ariana de Campos, Bento Ferreira, Carlos Alberto Moreira dos Santos. Synthesis of $\mathrm{SnSb}_{2} \mathrm{Te}_{4}$ Microplatelets by High-energy Ball Milling. Mater. Res. 2015. V. 18. No 5. P. 953-956.

26. Karpinskii O.G., Shelimova L.E., Kretova M.A. X-Ray Diffraction Study of Mixed Layer Compounds in the Pseudobinary System $\mathrm{SnTe}-\mathrm{Bi}_{2} \mathrm{Te}_{3}$. Neorg. Mater. 2003. V. 39. P. 305-311 [Inorg.Mater. (Engl. Transl.). V. 39. P. 240-246].

27. Lin Pan, Jing Li, David Berardan, Nita Dragoe. Transport properties of the $\mathrm{SnBi}_{2} \mathrm{Te}_{4}-\mathrm{PbBi}_{2} \mathrm{Te}_{4}$ solid solution. Solid State Chem. 2015. V. 225. P. 168-173.

28. Vilaplana R., Sans J.A., Manjón F.J., Andradachacón A., Sánchez-Benítez J., Popescu C., Gomis O., Pereira A.L.J., García-Domene B., RodríguezHernández P., A.Muñoz D., Daisenberger Oeckler O. Structural and electrical study of the topological insulator $\mathrm{SnBi}_{2} \mathrm{Te}_{4}$ at high pressure. J. alloys and compounds. 2016. V. 685. P. 962-970.

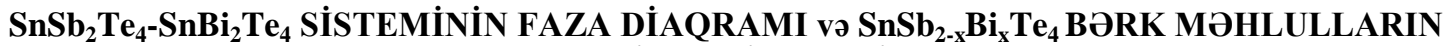 BəZİ XASSISOLӘRI}

\section{A.E.Seyidzadə, M.B.Bbanlı}

Differensial termiki və rentgenfaza anlizləri üsulları ilə $\mathrm{SnSb}_{2} \mathrm{Te}_{4}-\mathrm{SnBi}_{2} \mathrm{Te}_{4}$ sistemində faza tarazlıqları öyrənilmiş və faza diaqramı qurulmuşdur. Müəyən edilmişdir ki, sistem ilkin birləşmələrin inkonqruent ərimələri səbəbindən qeyrikvazibinardır, lakin solidusdan aşağıda stabildir və tetradimitə bənzər heksaqonal quruluşa malik fasiləsiz bərk məhlul sırası əmələ gətirir. Sistemin likvidusu SnTe birləşməsi əsasında bərk məhlulun ( $\alpha$-faza) ilkin kristallaşma əyrisindən ibarətdir. Likvidusdan aşağıda $\mathrm{L}+\alpha \leftrightarrow \gamma$ peritektik reaksiyası üzrə $\mathrm{SnSb}_{2} \mathrm{Te}_{4}$ və $\mathrm{SnBi}_{2} \mathrm{Te}_{4}$ birləşmələri arasında bərk məhlul ( $\gamma$-faza) əmələ gəlir. Ovuntu diffraktoqramları əsasında bərk məhlulların qəfəs parametrləri hesablanmış və müəyyən edilmişdir ki, onlar tərkibdən xətti asılıdırlar.

Açar sözlər: $\mathrm{SnSb}_{2} \mathrm{Te}_{4}-\mathrm{SnBi}_{2} \mathrm{Te}_{4}$ sistemi, faza tarazlı̆̆l, bərk məhlul, tetradimitə bənzər quruluş, qalay-bismut-sürmə teluridlari.

\section{ФАЗОВАЯ ДИАГРАММА СИСТЕМЫ $\mathrm{SnSb}_{2} \mathrm{Te}_{4}-\mathrm{SnBi}_{2} \mathrm{Te}_{4}$ И НЕКОТОРЫЕ СВОЙСТВА ТВЕРДЫХ PACTBOPOB $\mathrm{SnSb}_{2-\mathrm{x}} \mathrm{Bi}_{\mathrm{x}} \mathrm{Te}_{4}$}

\section{А.Е.Сеидзаде, М.Б.Бабанлы}

Методами ДТА и РФА исследованы фазовые равновесия в системе $\mathrm{SnSb}_{2} \mathrm{Te}_{4}-\mathrm{SnBi}_{2} \mathrm{Te}_{4}$, построена ее $T-x$ диаграмма. Установлено, что система неквазибинарна из-за инконгруэнтного характера плавления исходных тройных соединений, но стабильна ниже солидуса и характеризуется образованием непрерывного ряда твердых растворов замещения с тетрадимитоподобной гексагональной структурой. Ликвидус состоит из одной кривой, отвечающей первичной кристаллизации твердых растворов на основе соединения $\operatorname{SnTe}(\alpha-\phi а з а)$, которая, взаимодействуя с жидкой фазой по перитектической пеакции ( $\mathrm{L}+\alpha \leftrightarrow \gamma)$, образует твердые растворы на основе соединений $\mathrm{SnSb}_{2} \mathrm{Te}_{4}$ и $\mathrm{SnBi}_{2} \mathrm{Te}_{4}$. По результатам порошковых диффрактограмм определены параметры кристаллической решетки. Установлено, что параметры кристаллической решетки твердых растворов линейно меняются с составом.

Ключевые слова: система $\mathrm{SnSb}_{2} \mathrm{Te}_{4}-\mathrm{SnBi}_{2} \mathrm{Te}_{4}$, фазовое равновесие, твердый раствор, тетрадимитоподобная структура, теллуриды олово-висмут-сурьма. 